\title{
Political mechanics of smallness: The Baltic States as small states in the European Parliament
}

\author{
Allan Sikk \& Licia Cianetti \\ University College London, School of Slavonic and East European Studies
}

The impact of state size on macroeconomics, political economy and international politics is well established in academic literature. When it comes to domestic politics, the received wisdom is that nearly all contemporary democracies are too big to benefit from advantages assigned to small political communities, following the conclusion from Dahl \& Tufte's seminal Size \& Democracy (1973). However, there is evidence on the impact of country size on the size of parliaments, democratic endurance, civil conflict, electoral turnout and party membership levels. ${ }^{1}$ Still, much of the research is exploratory in nature and the mechanisms by which state size affects political variables remain understudied.

Anckar (2002) is among the few to break the mould as he argues that smaller country size means smaller distances between elites and citizens and, as a result, interest articulation is filtered through fewer intervening structures and agents. This chapter analyses the working of such intermediate institutions in the Baltic states. More specifically, we look at the members of European Parliament (MEPs) by analysing patterns of representation in the committees and political groups of the European parliament and on national party boards. Small country size in conjunction with party system fragmentation has led to MEPs being scattered among the organs of the European Parliament (EP) and to their negligible representation on party boards. This can both reduce the influence of the Baltic states within the EP, but also the influence of MEPs within their parties and, by implication, reduce the EUrelated policy expertise and the even the overall importance of political relevance of the EU in domestic politics.

At the same time, we discover that the MEPs from the Baltic states are politically more experienced than MEPs from larger countries, despite their arguably more marginal position. We find that in general country size is negatively correlated with national political experience of MEPs, so that the levels of experience are higher in smaller member states, and particularly in new member states - such as the Baltic states. We propose a theoretical model for the relationship and also discuss additional factors (shorter length of political career paths and attractiveness of MEP status) that can further strengthen the relationship in the Baltic states.

\footnotetext{
${ }^{1}$ See on size and parliaments: Taagepera \& Shugart 1989, Taagepera \& Recchia 2002, Taagepera 2007; small size conducive to democracy: Srebrnik 2004, Ott 2000; large size conductive to democracy: Erk \& Veenendaal 2014, Gerring \& Zarecki 2011, Clague, Gleason, and Knack 2001; civil conflict: Brückner 2010, Collier \& Hoeffler 2009, Fearon \& Laitin 2003, Hegre \& Sambanis 2006; turnout: Geys 2006: 642-3, Blais 2000, p.59; party membership: Weldon 2006.
} 
This higher level of national parliamentary and cabinet experience may compensate both for the small numbers of representatives in the EP and the small number of MEPs on party boards. Particularly those MEPs who have served in national cabinets have, as ministers, interacted with the national parliaments and the EU (both the European Commission and the EU ministerial level meetings). Hence, such MEPs and, by implication, their countries and national parties are ceteris paribus at an advantage when it comes to using argumentative and lobbying strategies (see Panke, this volume) in asserting influence in the European Parliament.

\section{Baltic states and the political impact of size}

Estonia, Latvia and Lithuania are often included in studies on European small states and have also been the subject of many case studies focussing on the political and economic effects of country size. Interest in the small Baltic states intensified after their accession to the EU and NATO and in the wake of the Great Recession that hit them particularly hard. While the small size of these countries has often been used as an explanatory or intervening variable, the specific mechanisms through which size affects politics - especially domestic politics - are relatively uncharted.

Most studies that include the Baltic states have concerned political economy or foreign policy - including studies of all European small states and those that focus specifically on one or more Baltic states (most frequently Estonia). Although they define smallness in various ways, they generally tend to assume that it leads to vulnerability and limitations and look at their economic, political or defence implications. Studies on foreign politics have focussed particularly on international security and negotiations in the EU. In international and security studies, size is typically related to a country's capacity to project power and defend itself. These studies argue that we need to take small size into account in order to understand Baltic foreign policy, especially as it entails specific vulnerabilities and limits international capabilities (Trapans 1998; Männik 2004) and influence on agenda-setting in international organisations (Galbreath and Lamoreaux 2007; Lamoreaux and Galbreath 2008; Archer 2010; Crandall 2014). The effects of smallness are often intermingled with effects of other factors, such as proximity to Russia (Archer 2010), membership in regional organisations (Männik 2004; Lamoreaux and Galbreath 2008), or international political economy (Kattel et al. 2010). As a consequence, country size is often seen as an important, but fuzzy background condition.

Some of the same themes surface in studies on negotiating strategies in the EU. Especially after the 2004 enlargement, size differences in the EU and their implications for decisionmaking practices have attracted academic attention. Estonia, Latvia and Lithuania are typically included in comparative studies of European small states (Bunse et al. 2005; Thorhallsson 2006; Panke 2010, 2012, this volume; Steinmetz and Wivel 2010). Like the literature on foreign policy and security, studies of EU decision-making assume that smallness limits the negotiating strategies of small states. Opportunities and possible ways to overcome those 
limitations are also highlighted; for example, Diana Panke looks at how small EU states can under certain conditions 'punch above their weight' in EU negotiations (Panke 2010, 2012).

These studies provide useful insights into small states' negotiating capabilities and strategic possibilities within the EU. Smallness is seen as an important constraining factor, but the mechanisms through which small size actually affects the political process are often not considered in detail. One exception is a study commissioned by the EU Affairs Committee of the Estonian Parliament, which focuses specifically on Estonia's officials and their strategies vis-à-vis EU institutions (Made 2010). Made posits small size as one of the main factors in Estonia's EU-policies, in terms of limited resources, perception of the country's own potential, and strategic constraints. Through his close focus on Estonian officials, he provides useful insights on the differences between Tallinn-based and Brussels-based officials, their perceptions of country size and influence, and their strategies for dealing with size-related limitations. He argues the small number of EU policy experts can result in high workload and multitasking, which can affect the quality of decision-making. ${ }^{2}$

The analysis of Estonian party politics after EU accession by one of the authors of this chapter is another attempt at uncovering the mechanics behind the influence of size (Sikk 2009a). The effects of EU membership on party politics were found to be mediated by the small size of the country. The small number of European policy specialists and of MEPs means that they have limited presence in the decision-making bodies of political parties, which can contribute to the side-lining of European issues in favour of domestic concerns. However, a broader comparative framework is necessary for clearly identifying the specific effects of smallness beyond the case of Estonia.

In this chapter, we focus on the effects of country size on EU politics by looking at the numbers and role of MEPs from the Baltic states. MEPs are arguably the most prominent European specialists - party politically speaking - and a crucial link between (national) political parties and European politics. Through a comparative analysis and theory building on the impact of size on the numbers, distribution, status and background of MEPs, this chapter complements findings from other studies to uncover some of the elementary mechanisms through which size matters. Our theoretical arguments and those stemming from the quantitative comparative analysis are complemented and tested by in-depth look at the MEPs from the Baltic states. For the most part, we use size as a continuous rather than a dichotomous variable as that allows us to develop more general theoretical models and alleviates the need to come up with (potentially arbitrary) cut-off points. We look at the Baltic states as countries at the extreme low end of the scale and use the specific detail to illustrate the general effect of size.

\footnotetext{
${ }^{2}$ Still, given the study's aim to provide policy recommendations, it does not clearly distinguish between effects related to size and other factors (such as the short period of EU membership).
} 
We show that even though small countries are overrepresented in the EP relative to their size, the small absolute number of MEPs has implications on both coverage of issue areas in the EP and their involvement within party organs. However, country size also has an effect on the level of national political experience of MEPs. MEPs from small member states tend to have more experience in national politics than those from larger member states. This can imply stronger linkages to national politics and can compensate for the small numbers in terms of the quality of representation. ${ }^{3}$ We also propose an underlying theoretical model for the relationship between size of representation and national political experience and finish with a discussion of intervening and additional factors, some of which can independently linked to country size.

\section{Country size and representative institutions}

The size of national delegations in EP is linked to country size by the principle of "degressive proportionality" where some of the specifics have been influenced by historical bargaining (see Corbett et al. 2011: 27-29) (see Figure 1). The average ratio is three MEPs per million people, but it is much more favourable for smaller member states than large member states. Hence, there are 4.5 MEPs for one million Estonians, yet only 1.2 per million Germans; Luxembourg and Malta have the most favourable ration of about 12 MEPs per million. Taagepera \& Hosli (2006) develop a logical model linking the size of country's population and national representation in EP (or any other international organization):

$$
S_{i}=\frac{S P_{i}^{n}}{\sum P_{k}^{n}}
$$

where $S_{i}$ is the number of seats for country $i, S$ stands for the total number of seats available, $P_{i}$ total population in country $i$ and $n$ is an exponent equal to:

$$
n=\frac{\left(\frac{1}{\log N}-\frac{1}{\log S}\right)}{\left(\frac{1}{\log N}-\frac{1}{\log P}\right)}
$$

where $\mathrm{N}$ is the number of member states, $\mathrm{S}$ the total number of seats and $\mathrm{P}$ total population (of the EU). The line based on the logical model on Figure 1 fits the line well (close to the empirical linear OLS fit, not shown), but the two smallest member states as well as Germany (the biggest member state) are clearly overrepresented. ${ }^{4}$

\footnotetext{
${ }^{3}$ Possibly, it also alleviates disconnect that may result from a physical distance between Brussels and national capitals.

${ }^{4}$ The reasons why Germany is overrepresented are discussed in some detail in Corbett et al (2011: 27-29). Malta and Luxembourg benefit from a legally stipulated minimum number of seats per member state - according to the Taagepera \& Hosli model, their delegations would include three and four MEPs, respectively. Please note that the seat distribution refers to pre-Lisbon Treaty allocation as data from Corbett et al. (2011) used later in the chapter refers to that period. Post-Lisbon Treaty seat allocation would fit the Taagepera \& Hosli model even better as the total number of seats increased while the numbers of German and Maltese MEPs were reduced.
} 
Figure 1 Country size and number of MEPs

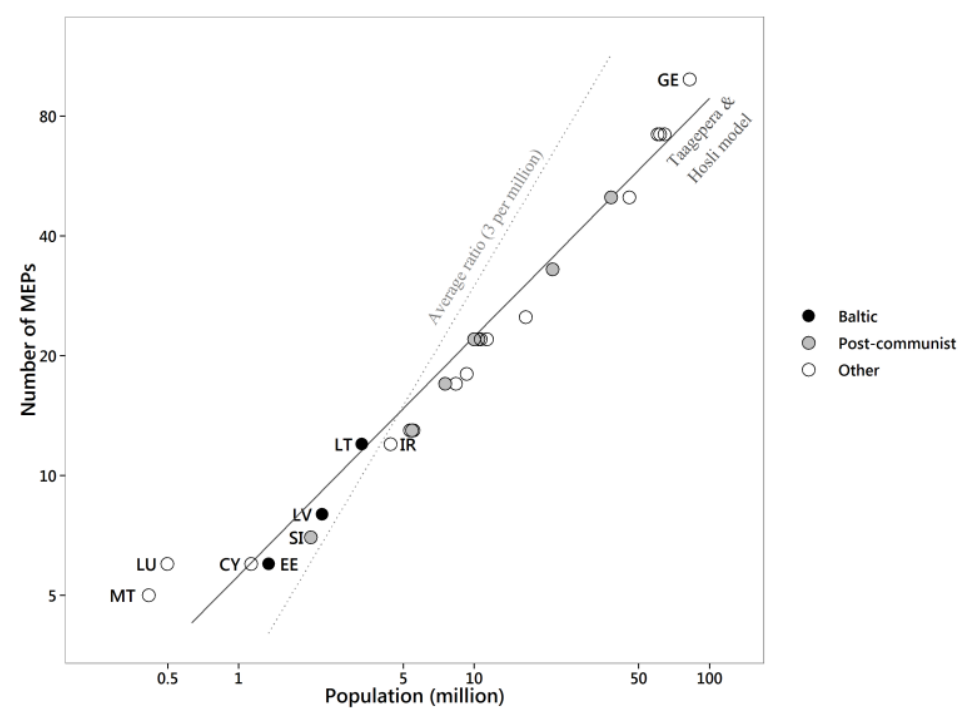

A similar relationship holds for the number of seats in national parliaments. For an obvious reason it is less strong than that between the country size and EP delegation - the size of national parliaments has been decided independently by individual countries. As argued by Rein Taagepera and his colleagues, the total number of seats in national assembly approximately follows the cube root of total population. They argue that the cube root formula minimizes the workload of representatives by optimizing the number of communication channels between representatives and constituents and representatives themselves (see Taagepera \& Shugart 1989, p.175; Taagepera 2007: Ch.12). The size of national parliaments in EU member states follows the cube root function very closely, with parliaments in larger member states being slightly "oversize" and those in smaller member states slightly "undersize" (see Figure 2).

Figure 2 Country size and size of parliament (lower houses)

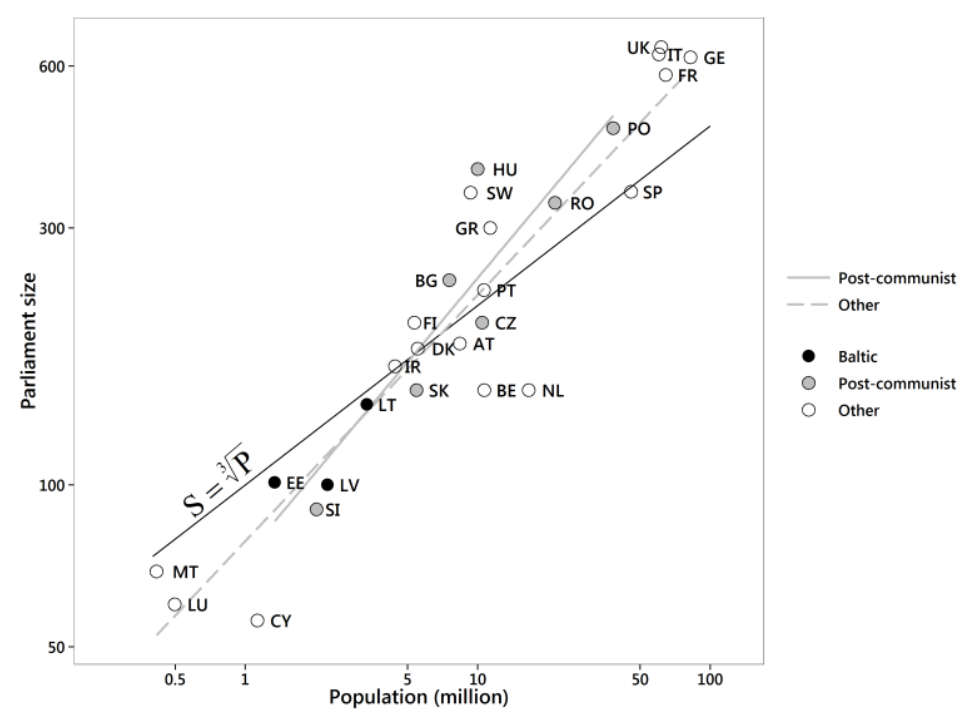

Note: Grey lines show empirical OLS fits. 
Finally, cabinet size is also related to country size. It is positively, albeit weakly, linked to total population $\left(R^{2}=0.26\right)$, with relatively smaller cabinets in post-communist countries, controlling for country size (see the lower empirical OLS fit line on Figure 3). However, there are many outliers - such as Hungary, Malta and the Netherlands with undersized and Sweden and Finland with oversized cabinets. The reasons why larger countries tend to have larger cabinets are not immediate clear and remain beyond the scope of this chapter. At this point, we can only speculate that it may be related to more limited resources, a smaller number of significant issue areas in smaller countries; the variation also partly stems from different institutional arrangements and notions of what constitutes a cabinet.

Figure 3 Country size and cabinet size

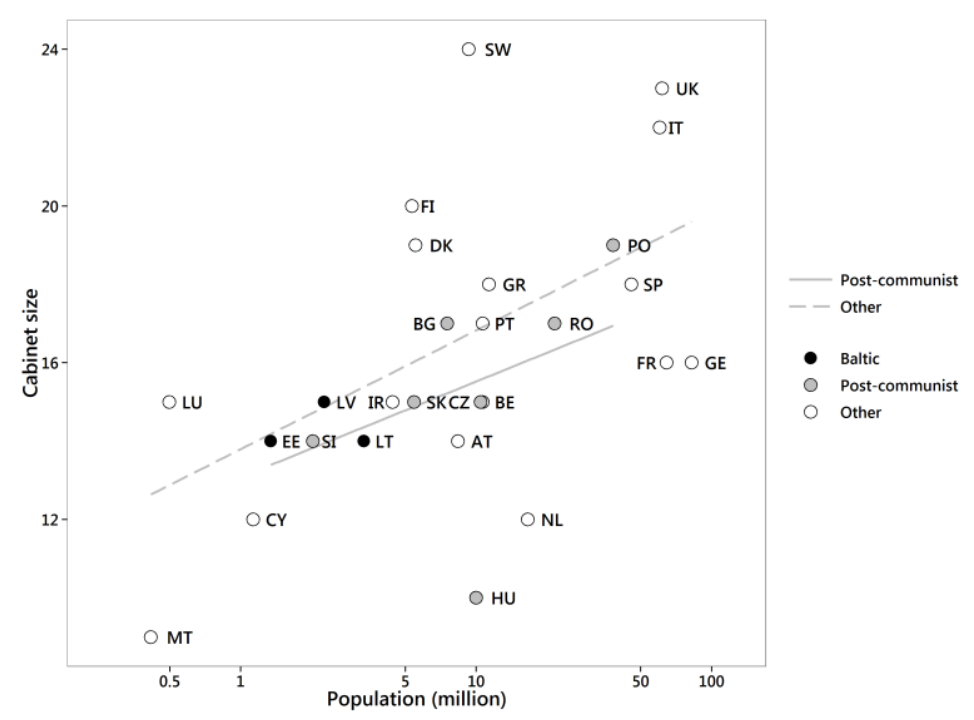

Source: Number of cabinet members from Andersson et al. (2014).

\section{European Parliament party groups and committees}

Small country MEPs can sometimes punch above their weight and yield disproportional influence in the Parliament. Regardless of their background and even the size of delegations, MEPs form small countries can enjoy more power by being kingmakers. One specific example is the establishment of party groups. A party group needs to have at least 25 representatives from at least a quarter of member states (Corbett et al. 2011, p.78). Baltic MEPs have been highly sought-after at times in recent years. For example, the Europe of Freedom and Direct Democracy (EFDD) group led by United Kingdom Independence party (UKIP) and the Italian Five Star Movement disintegrated on 14 October 2014 when a Latvian MEP (Iveta Grigule of the Union of Greens and Farmers) decided to leave the group but was soon reinstituted when an MEP from the Polish Congress of the New Right (Robert Iwaszkiewicz) ${ }^{5}$ decided to join. In

\footnotetext{
5 See “Farage's Eurosceptic Group Collapses, Sakharov Prize Winner Postponed." EurActiv, http://www.euractiv.com/video/farages-eurosceptic-group-collapses-sakharov-prize-winner-postponed30925716 October 2014 and "Farage's Eurosceptic Group Saved by Polish MEP." EurActiv, 21 October 2014.
} 
2009, the establishment of European Conservatives and Reformists (ECR) group hinged upon recruiting members from a sufficiently large number of member states. Out of this necessity, ECR joined forces with a nationalist Latvian party (TB-LNNK) with just one MEP amongst other, often controversial - parties from Central and Eastern Europe (Bale et al 2010). ${ }^{6}$ In the same year, Indrek Tarand, an anti-party independent candidate, was successful in his bid to become an MEP for Estonia. Before eventually joining the Greens-European Free Alliance (GreensEFA) group, he was courted by no less than four other groups - the Alliance of Liberals and Democrats for Europe (ALDE), the Party of European Socialists (PES), ECR and the group of the non-attached (Sikk 2009b; Ehin and Solvak 2012). ${ }^{7}$

EP committees have been growing in importance as the significance of EP itself has grown. It has been shown that committee members possess high levels of expertise on the policy areas of the committees (McElroy 2006)(McElroy 2006). Due to the high number of committees (20 as of 2014-15), only bigger member states can have representatives in all committees. ${ }^{8}$ The Baltic states are very far from that, given their very small number of MEPs. One strategy of overcoming the problem of small size could be cooperation. Between them, the Baltic states have 24 MEPs and if the choice of committees were carefully coordinated, they might just be able to cover all the committees between them.Such coordination is only hypothetical because of partisan divides and at best limited sense of common identity. Toomas-Hendrik Ilves, the most popular candidate in 2004 European elections in Estonia (former foreign minister and later the country's president) made his views on 'Baltic unity' clear in a 1999 speech entitled 'Estonia as a Nordic country': '... it is time to do away with poorly fitting, externally imposed categories. It is time that we recognise that we are dealing with three very different countries in the Baltic area, with completely different affinities.' (cited in Lehti 2006, p.71).

In practice, there is little evidence of coordination across national delegations. Indeed, even coordination amongst Baltic representatives belonging to the same EP group can be difficult if they come from parties that are adversaries in national politics. The Baltic delegations in the ALDE group are particularly notorious in that regard. Its Lithuanian members belong to the Labour Party (centrist, often characterized as populist and marred by corruption scandals) and the Liberal Movement (the most economically and socially liberal Lithuanian party). Both have at times been included in the governing coalitions, but always avoided each other. The Estonian members of the EP group belong to the free marketeer Reform party and the centre-

http://www.euractiv.com/video/farages-eurosceptic-group-saved-polish-mep-309367 (accessed 15 January 2015).

${ }^{6}$ ECR only narrowly met the requirement to include MEPs from at least seven member states.

7 Also see "Nädala Tegija", Radio Kuku, 10 July 2009 (in Estonian, http://podcast.kuku.ee/2009/07/10/nadalategija-2009-07-10/, accessed 12 January 2015) where Tarand discussed his negotiations with various groups openly and in rich detail.

${ }^{8}$ Substitute members have few disadvantages over full members (Corbett et al. 2011, p.146) and we look at them in the following discussion. 
left Centre party (with a controversial dominant leader and a particular stronghold amongst the Russian speaking minority) that have in recent decades been foes in Estonian party politics. Even stranger bedfellows can be found when looking at MEPs from all three Baltic states together. The Greens-EFA have three members from the Baltic states: Bronis Rope (Lithuania), Tatjana Ždanoka (Latvia) and Indrek Tarand (Estonia). Rope is the vice-chair of the agrarian and Eurosceptic Lithuanian Peasant and Greens Union. Tatjana Ždanoka is a co-chair of hard-line Russian Union and was once barred from running to the national parliament because of continued membership in the Communist Party after it had called for a coup against the democratically elected pro-independence government in 1991. Yet, Indrek Tarand (an independent) used to be the Secretary General of the Ministry of Foreign Affairs during the EU membership negotiations and is also known for his fervent anti-communism infamously for a controversial public prank against former communist top politicians in Estonia. $^{9}$

Therefore, because of the combined effect of small numbers of MEPs and lack of coordination between them, two committees (Development and Constitutional Affairs) were without any Baltic representatives - even when including substitute members. ${ }^{10}$ Further three (Economic and Monetary Affairs, Fisheries and Legal Affairs) only included substitute members from the Baltic states. In addition to coordination problems, a key reasons for the uneven distribution of MEPs in committees is the popularity of some committees.

The Foreign Affairs Committee, in particular, has for long been the committee of choice for Baltic MEPs as it included five full members from the Baltic states - with three from Latvia alone. Together with the substitutes, seven Baltic MEPs were involved in the work of the committee - nearly a third of all Baltic MEPs. The situation has been similar since at least 2008 (see Sikk 2009a) when the Foreign Affairs Committee included as many as nine members (four members and five substitutes). In 2008, the Security and Defence sub-committee was particularly popular among Baltic MEPs - it also had vice-chairs from Latvia and Lithuania. ${ }^{11}$ In 2015, the committee on Industry, Research and Energy was also popular with five full members and one substitute.

The concentration on some committees (and absence from others) may be a sign that Baltic MEPs chose to focus on issue areas more significant to them and their constituents, hoping to make a difference there. This corresponds to the strategy of prioritization in the European Commission discussed by Diana Panke in her chapter in this volume. The focus on Foreign Affairs is expected as the membership in the EU was to great extent seen as a foreign policy

\footnotetext{
${ }^{9}$ See Sikk 2009b, p.4.

10 The data here and below refer to the situation as of January 2015.

11 In 2008 the distribution was generally more even as there was at least one Baltic representative in all committees (three with substitute members only). However, the total number of Baltic MEPs has decreased by three since then.
} 
project and part of the grand turning back on communist history by 'returning to the West' (see Tulmets 2014). High membership in Industry, Research and Energy are explained by the relevance of EU energy policy for all states, but for Lithuania in particular. Following the EU accession the country had to close its nuclear power station in Ignalina (Ivanov 2008) and the future of sustainable electricity production has since been a pre-occupation for the country. Typically, three Lithuanian MEPs (27 percent of the national delegation) have been sitting on the committee as full or substitute members.

The size of individual party delegations from the Baltic states is further affected by the fragmentation of party systems. The average size of a party delegation in EP is four - even theoretically far beyond the reach for almost all Baltic parties. Indeed, Estonia has the lowest average size of party delegations (1.2). Note that Italy has the highest average party delegation (10.3) despite a fairly fragmented party system - that shows how much more difficult it is for parties from small member states - even with lower fragmentation - to have anything but a niche presence in EP. In 2014, 16 parties from the Baltic states - four from Estonia, five from Latvia and seven from Lithuania - entered the EP, ten of them with only one representative. Only Unity from Latvia managed to send a "delegation" in a meaningful sense of the word by winning four seats. However, this is generally highly unlikely, given the multi-party systems and proportional electoral systems in the Baltic states.

\section{MEPs and national party organs}

Due to the small overall number of Baltic MEPs and rather fragmented party systems, the representation of MEPs on party boards is very low. As of 2015 Unity (V) in Latvia is an exception as three out of its four MEPs are members of the party board - a respectable fifth of all members. ${ }^{12}$ However, that was only made possible by the surprisingly strong performance by the party in the 2014 European elections; its support more than halved in parliamentary elections only five months later. No other Baltic party has as many MEPs, the maximum among all others being two - limited to four Lithuanian parties and one Estonian party. Hence, numerically speaking, the MEPs are bound to remain a tiny minority on party boards.

When looking at Baltic MEPs from the perspective of national delegations in the Parliament, their profile within their (national) parties has generally been high. Typically, more than half of them have either been party board members or in an even more senior position. Hence, in January 2015, 16 out of 25 Baltic MEPs (64\%) had been elected to their party boards and seven (28\%) of them were either vice-chairs or leaders of their parties - the Lithuanian MEPs

\footnotetext{
12 The "European" connection is further strengthened by the presence of Andris Piebalgs, former EU commissioner.
} 
Rolandas Paksas (Order and Justice) and Valdemar Tomaševski (Electoral Action of Poles). Another Lithuanian MEP - Viktor Uspaskich - is the honorary chairman of the Labour Party that he set up in 2003, but he stood down from leadership in 2013 after he was found guilty of fraudulent bookkeeping. Two other MEPs from Estonia (Marju Lauristin) and Lithuania (Algirdas Saudargas) are former ministers and very eminent politicians highly respected by their parties.

The MEPs who do not have leadership positions in their parties are mostly people who do not have prominent party political careers behind them and owe their success to other factors. These include an independent (Tarand, see above), a well-known former professional poker player (Antanas Guoga from Lithuania), and a 33-year-old grandson of Vytautas Landsbergis, one of the most eminent Lithuanian post-independence politicians (Gabrielius Landsbergis). Two of the Latvian MEPs benefitted from the open list system (used in all three Baltic states) and high number of personal preference votes. Andrejs Mamikins (prominent journalist) and Iveta Grigule (ran an expensive personal campaign funded by unnamed benefactors) became successful despite their relatively low standing on their parties' candidate lists (fourth and third, respectively). Grigule had been a member of national parliament since 2010, but had left the Green Party after irregularities in her campaign funding that had financial consequences for the party; she joined the Latvian Farmer's Union (the second party in the electoral coalition) in the run-up to the European elections.

\section{Country size and national political experience of MEPs}

The previous section painted a rather bleak picture of atomized small country MEPs who can cover only a limited number issue areas - even between all MEPs from the three Baltic states - and whose voice is weak in national party organs. However, these limitations can partly be compensated by their national political experience - that can, in turn, also be a function of small size.

The Baltic MEPs have among the highest levels of previous experience in national parliament and cabinet amongst all EU member states. In 2009, nearly a third of MEPs (31\%) had been former PMs or presidents (see Figure 4). ${ }^{13}$ Overall, small and post-communist countries seem to have higher levels of experience - Slovakia and Slovenia are close to the Baltic states and nearly all post-communist countries have a higher than average score on both of the indexes.

\footnotetext{
${ }^{13}$ After 2014 elections the share of MEPs from the Baltic states with ministerial experience dropped to levels common in countries of similar sizes; the share of Latvian MEPs with parliamentary experience dropped somewhat from the extremely high level. Note, however, that due to the small number of MEPs from these countries, a change in the background of just one MEP can change the percentages considerably.
} 


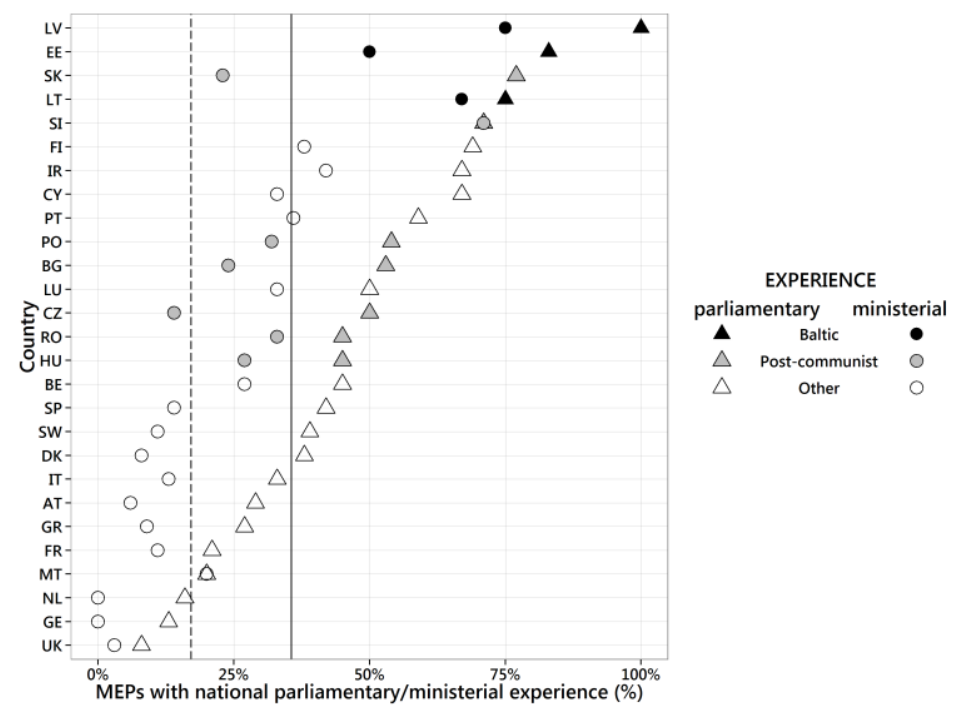

Source: based on Corbett et al. 2011, pp.56-58.

Note: vertical lines indicate average parliamentary (solid) and ministerial (dashed) experience.

It is obvious from Figure 4 that MEPs from smaller member states tend to have more experience in national politics. We study the relationship in more detail below, but first propose a very basic theoretical model to outline our expectations. In short, we argue that political elites tend to be more concentrated in smaller countries and the effect is not only due to smaller population but mediated by the effect that size has on intermediate institutions - specifically, the size of EP delegation, the size of national parliament and cabinet size.

\section{A theoretical model}

Before looking at the empirical relationship between relationship between country size and MEPs' experience in national parliaments, it might be useful to discuss our theoretical expectations. That can be done by logical models as proposed by Taagepera (2008). We can argue that the relationship is anchored at $100 \%$ for a (hypothetical) single MEP (for a discussion on anchor points, see Taagepera 2008, p.98). If there was a tiny member state that only had a single MEP, it would be extremely likely to be someone who has also had a chance to serve in the national parliament. On one hand, such prominent national politicians would have an electoral advantage and, on the other hand, such a candidate must have been a political 'talent' who would have been an MP at some point in her career.

An anchor point is much more difficult to establish at the other end of the scale. We can expect the share of former MPs to decrease with increasing size of the national delegation in EP. Some MPs can choose not to continue their careers in the European Parliament. For the sake of argument, let us consider a national parliament in a hypothetical huge country with 500 MEPs - roughly what a country the size of China would get under the current formula. If the parliament of that massive country followed the cube root law (see above and Taagepera 
2007, pp.188-9), it would have around 1,000 members. Hence, the EP delegation would come to challenge the national parliament in terms of its size. Consequently, it would be likely that many MPs would not aim to become MEPs and others will be building up their careers focussed on the European rather than national parliament as there are almost equal amount of opportunities.

It is difficult to suggest an exact shape for the function. We can only speculate that it decreases constantly as the number of MEPs multiplies (hence the use of logarithmic scale below) and establish the rate of change empirically. When fitting a constrained regression (that forces the best fit line to go through the anchor point), $0 \%$ is reached at about 300 MEPs (see Figure 5 ). ${ }^{14}$

Figure 5 shows that there is a broad negative relationship between the number of MEPs and their experience in national parliaments, and by extension between the country size and experience. Overall, the number of MEPs (logged) explains $36 \%$ of the variation in their parliamentary experience, the percentage predicted by ordinary least squares regression decreasing from 70\% (for countries with 5 MEPs) to only 22\% (for countries with 95 MEPs). However, there is a fair amount of scatter around the statistically modelled relationship much of it is explained by the history of member states. On average, the parliamentary experience of MEPs from the formerly communist member states is some $23 \%$ percentage points higher compared to West European (not formerly communist) member states, when controlling for the effect of country size - indicated by the raised linear fit line for postcommunist countries in Figure 5.

Some of the outliers may be explained by very small national parliaments relative to the population (for example the Netherlands, see Figure 2). Interestingly, nearly all states above or near the line are new (or newish) member states - the post-communist countries, but also Spain, Portugal, Finland, Cyprus - as well as Italy with its newish party system largely created around the time of communist breakdown in Eastern Europe. However, the same does not apply for Sweden, Austria, or in particular Malta, which MEPs have unusually low parliamentary experience for such a small country.

\footnotetext{
${ }^{14}$ However, such extrapolation carries dangers, especially as we ought to assume that the share with national parliamentary experience approaches $0 \%$ asymptotically but never falls below that. Such more sophisticated model is beyond the scope of this chapter.
} 
Figure 5 Number of MEPs and MEPs' experience of national parliament

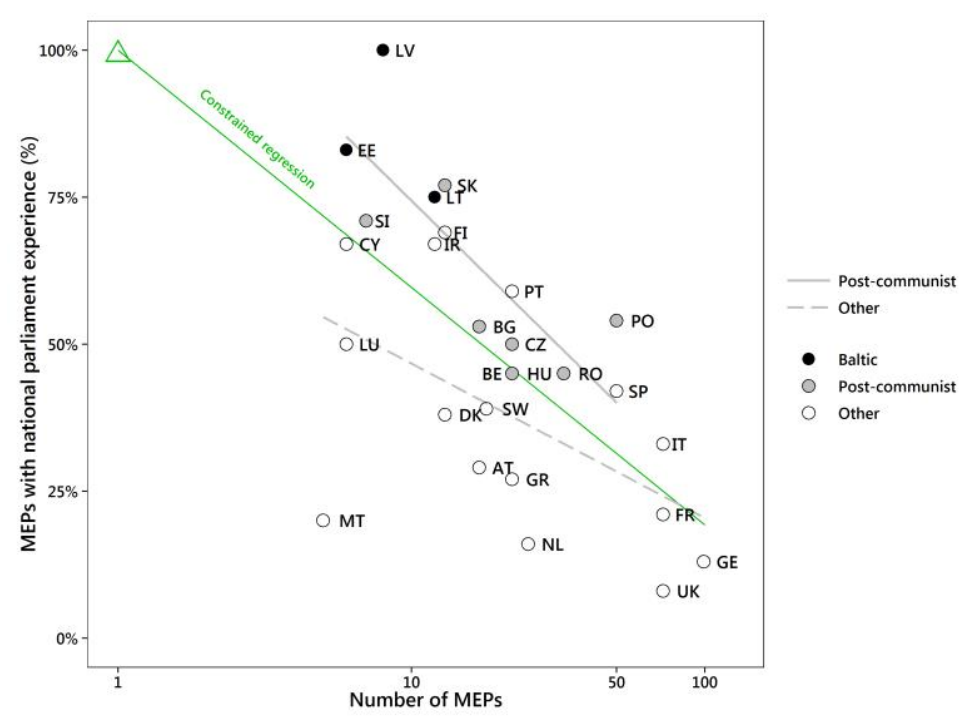

Note: Hollow triangle is an anchor point (see text). Source: see Figure 4.

The empirical relationship between the number of MEPs and their national ministerial experience is nearly as strong as the (logged) number of MEPs explains 33\% of the variation in experience (see Figure 6). ${ }^{15}$ Again, the MEPs from post-communist member states carry more ministerial experience (some 20 percentage points higher on average). Unsurprisingly, the overall level of previous ministerial experience is lower than national parliamentary experience - the number of cabinet positions is more limited both in terms of available seats and in terms of parties that win seats in national parliament yet have seldom or never been in government (see below).

\footnotetext{
${ }^{15}$ We have not used constrained regression here as it is difficult to determine the anchor point. A similar logic as used under parliamentary experience ought to apply but forcing the regression through the same anchor point would fit the empirical data very poorly. The intercept for (non-constrained) linear regression is at $68 \%$ only. A more advanced theoretical model should also take into account the actual size of cabinets or parliaments - these are correlated to country size (and the number of MEPs) but there is significant variation at similar country sizes (see Figure 2 and Figure 2Figure 3 above).
} 
Figure 6 Number of MEPs and MEPs' national ministerial experience

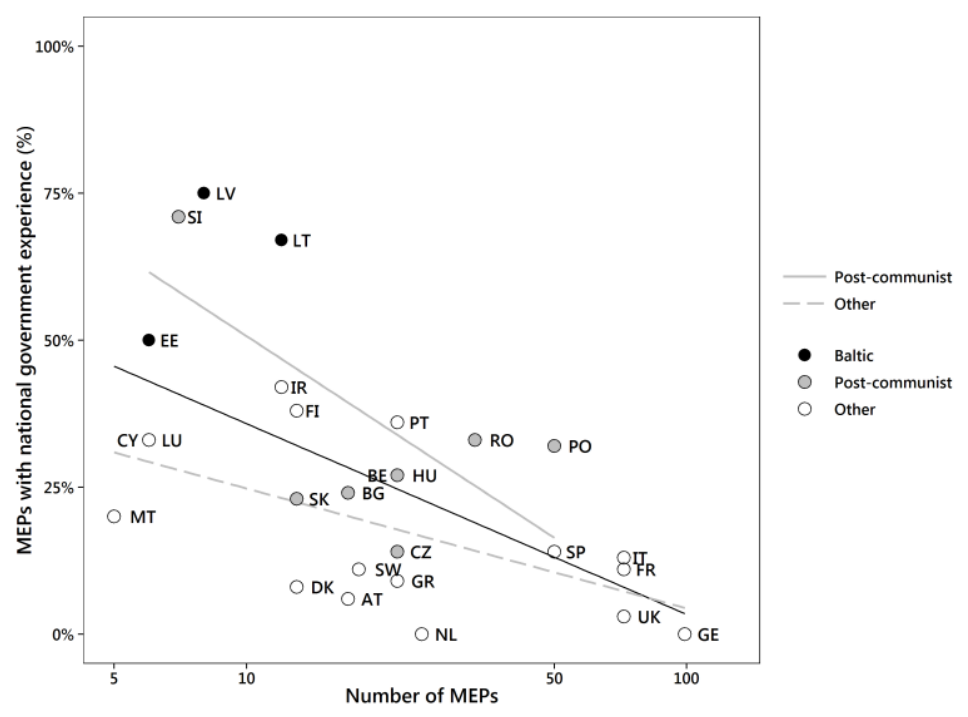

It is easy to see why MEPs from small member states could be relatively experienced. Even though cabinets tend to be smaller in small member states, they are bigger relative to the number of MEPs. For example, Luxembourg has 2.5 cabinet members per MEP while, at the other end of spectrum, Germany has more than six MEPs per cabinet member. In other words, that increases the probability of any MEP having sat in the national cabinet.

This effect is amplified in countries where governments change more often, as it gives more politicians a chance to serve in the cabinet. Notably the Baltic states - as nearly all small member states - tend to have relatively short-lived cabinets. ${ }^{16}$ However, several large member states have also had rather short-lived cabinets - such as France, Romania, Poland and, most notoriously Italy, that may explain the relatively high levels of experience given the size of EP representation. The combination of large cabinets with high cabinet turnover (i.e. low duration) particularly gives even more politicians a chance to serve as ministers. ${ }^{17}$

Another important intervening variable is the presence or absence of parties permanently excluded from national governments - some of which may be particularly or even only successful in European elections - such as the Danish June Movement that was represented in the EP until 2009 or UKIP that had had a sizeable representation in EP since 2004, yet did not win representation in the national parliament until 2014. Furthermore, the success of parties that have failed to enter national government further contributes to the low levels of ministerial experience among MEPs (most notably the French Front National or Danish People's Party). Among the Baltic MEPs, those from Latvia and Lithuania have high levels of ministerial experience. The countries combine medium-sized cabinets with very high levels of

\footnotetext{
${ }^{16}$ Luxembourg is an exception, the mean cabinet duration has also been slightly above the EU average in Ireland, Denmark and Finland (see Andersson et al. 2014).

${ }^{17}$ Further evidence on the combined effect of cabinet size and duration available on request.
} 
cabinet turnover - hence, the levels of ministerial experience are not surprising, especially as the governments in these countries have been rather inclusive of most major parties (with the exception of the predominantly Russophone Harmony Centre).

Additional potential explanations of higher levels of national political experience among MEPs from smaller and, in particular, newer member states include the typical length of political career paths, electoral systems and factors particular to new member states, principally postcommunist countries.

MEPs from smaller member states can also have more national political experience because of more limited political career opportunities on a national level. These tend to be more limited in smaller countries as the potential career ladder in national politics is shorter. People can become ministers at a lower age $\mathrm{e}^{18}$, as the ladder from junior political roles to the apex of national government is shorter due to less complex political hierarchy with fewer levels. Note that the argument here is close to the proposed tentative theoretical model for national parliamentary experience presented above. ${ }^{19}$

In theory, electoral systems might also affect the levels of national political experience among MEPs. In particular, we could speculate that the presence of preference voting may raise the profile of MEPs by giving an advantage to candidates tried and tested in national politics. Preference voting is used in all three Baltic states ${ }^{20}$ and may explain the particularly high levels of experience among Baltic MEPs. The absence of preference voting may explain the low levels of national experience in some of the member states (UK, France, Germany and Greece) and low levels for post-communist countries (Romania, Hungary). ${ }^{21}$ However, some countries with closed lists (Portugal and Spain) have fairly high levels of national political experience. Closed lists can, in principle, either allow the parties to enlist lesser known candidates or lead to stronger control over who can become an MEP, protecting the party elites against internal challengers.

\footnotetext{
${ }^{18}$ There is evidence that average age of ministers in democracies is positively correlated to country size and was particularly low in Estonia and Latvia (44.6 and 43.6, respectively, in 1999-2012). More detail is available on request from authors.

${ }^{19}$ Interestingly, extrapolating the empirical fits leads to intuitively sensible model predictions for hypothetical nano-countries. A society of 92 would have a cabinet with a single member on average (societies significantly smaller than that would lack formal institutions altogether). That is a reasonable expectation considering the nature of socio-political organization. The average age of ministers in such a country would be 36.6. That is, again, a rather reasonable expectation for a sole leader, on average. Note that we are assuming democracy otherwise the person may hold on to power and the mean age would increase significantly.

${ }^{20}$ The 2009 election in Estonia was an exception that may partly explain the relatively lower levels of experience there. The levels are lower than those in Latvia and Lithuania even when discounting the independent Indrek Tarand whose campaign strongly attacked the adoption of closed party lists (that were scrapped soon after the election).

${ }^{21}$ Data on electoral systems from Corbett et al. 2011, pp.17-18.
} 
The higher levels of experience among MEPs from post-communist countries (and other relatively new member states) may also be explained by the fact that the accession only took place recently and lower living standards in the countries. For political elites of new member states it was impossible to build up their careers focussing on the European level from early on and all aspiring politicians had to focus entirely on careers in national political institutions. Finally, service at the EP can be more coveted for politicians from new member states because the remuneration (including expenses) is better compared to national salaries for MPs or ministers. That may, yet again, lead to top spots on electoral lists being reserved for senior ranks within political parties.

\section{Conclusion}

This chapter discussed the political mechanics of county size by looking at the patterns of representation in the European Parliament and national political experience of MEPs. We found that the potential influence of Baltic MEPs in the European parliament is severely constrained by low numbers. It can also contribute to the separation of mainstream domestic politics and European issues (see Sikk 2009a) as MEPs are bound to remain a small minority among the leadership of national parties - an effect amplified by high party system fragmentation.

Furthermore, given the small number of MEPs from all three Baltic countries, the countries are unlikely to be represented in all EP committees. It can be argued that national expertise on certain European policy fields would suffer as a consequence even if the MEPs enthusiastically interacted across party and country lines. However, cooperation is scarce, often even between MEPs belonging to the same EP party group. Less pessimistically, the MEPs from the Baltic states have been prioritizing issue areas that are perceived to be particularly relevant or where they see an important role for EP (a strategy for countries to overcome their smallness mentioned by Panke in this volume). This mostly applies for external affairs, as the Foreign Affairs committee has constantly seen a steady representation of Baltic MEPs. Additionally, Lithuanian MEPs have been focussed on energy policies, explained by particular issues in the country.

However, we also show that the small numbers are partly compensated by the relatively high profile of Baltic MEPs, indicated by high levels of national political experience (as ministers and MPs) and leadership roles within national parties. We argue that there is a general negative correlation between such expertise and country size, further amplified in new member states that, that has led to very high levels of national political experience among the Baltic MEPs. Particularly the MEPs who have previously served as ministers have high levels of expertise on European policies and on executive-legislative interactions, acquired while negotiating between the European Union institutions as well as nationally between the executive and legislative institutions. Overall, the combination of higher than average 
expertise and prioritization help top alleviate the problems resulting from small numbers and problems of coordination between Baltic MEPs.

\section{Acknowledgements}

The authors wish to thank the editors of this volume and Rein Taagepera for helpful comments on an earlier draft of this chapter.

\section{Bibliography}

Anckar, D. (2002) 'Why are small island states democracies?', The Round Table, 375-390.

Andersson, S., Bergman, T., Ersson, S. (2014) 'The European Representative Democracy Data Archive, Release 3.'

Archer, C. (2010) 'Small States and the European Security and Defence Policy', in Steinmetz, R. and Wivel, A., eds., Small States in Europe. Challenges and Opportunities, Ashgate: Farnham, UK, 47-62.

Blais, A. (2000) To Vote Or Not to Vote?: The Merits and Limits of Rational Choice Theory, University of Pittsburgh Press.

Brückner, M. (2010) 'Population Size and Civil Conflict Risk: Is there a Causal Link?', The Economic Journal, 120(544), 535-550.

Bunse, S., Magnette, P., Nicolaïdis, K. (2005) 'Is the Commission the Small Member States' Best Friend?', Swedish Institute for European Policy Studies, Report, 9.

Clague, C., Gleason, S., Knack, S. (2001) 'Determinants of lasting democracy in poor countries: Culture, development, and institutions', The Annals of the American Academy of Political and Social Science, 573(1), 16-41.

Collier, P., Hoeffler, A. (2009) Democracy's Achilles Heel Or, How to Win an Election without Really Trying.

Corbett, R., Jacobs, F., Shackleton, M. (2011) The European Parliament, John Harper.

Crandall, M. (2014) 'Soft Security Threats and Small States: the Case of Estonia', Defence Studies, 14(1), 30-55.

Dahl, R.A., Tufte, E.R. (1973) Size and Democracy, Stanford University Press.

Ehin, P., Solvak, M. (2012) 'Party voters gone astray: explaining independent candidate success in the 2009 European elections in Estonia', Journal of Elections, Public Opinion \& Parties, 22(3), 269-291. 
Erk, J., Veenendaal, W. (2014) 'Is Small Really Beautiful?: The Microstate Mistake', Journal of Democracy, 25(3), 135-148.

Fearon, J., Laitin, D. (2003) 'Ethnicity, insurgency, and civil war', American political science review, 97(1), 75-90.

Galbreath, D.J., Lamoreaux, J.W. (2007) 'Bastion, Beacon or Bridge? Conceptualising the Baltic Logic of the EU's Neighbourhood', Geopolitics, 12(1), 109-132.

Gerring, J., Zarecki, D. (2011) Size and Democracy Revisited, DISC Working Papers, Budapest.

Geys, B. (2006) 'Explaining voter turnout: A review of aggregate-level research', Electoral Studies, 25(4), 637-663.

Hegre, H., Sambanis, N. (2006) 'Sensitivity analysis of empirical results on civil war onset', Journal of conflict resolution, 50(4), 508-535.

Ivanov, K. (2008) 'Legitimate conditionality? The European Union and nuclear power safety in Central and Eastern Europe', International Politics, 45(2), 146-67.

Kattel, R., Kalvet, T., Randma-Liiv, T. (2010) 'Small States and Innovation', in Steinmetz, R. and Wivel, A., eds., Small States in Europe. Challenges and Opportunities, Ashgate: Farnham, UK, 65-85.

Lamoreaux, J.W., Galbreath, D.J. (2008) 'The Baltic States As "Small States": Negotiating The "East" By Engaging The "West"', Journal of Baltic Studies, 39(1), 1-14.

Lehti, M. (2006) 'Eastern or Western, New or False: Classifying the Balts in the Post-Cold War Era', in Tassinari, F., Joenniemi, P. and Jakobsen, U., eds., Wider Europe: Nordic and Baltic Lessons to Post-Enlargement Europe, Copenhagen, Danish Institute of International Studies, 69-88.

Made, V. (2010) 'Successes and Failures in Representing Small State Interests in European Union Decision-Making: the Case of Estonia', Acta Societatis Martensis, 4(1), 109-138.

Männik, E. (2004) 'Small states: invited to NATO - able to contribute?', Defense \& Security Analysis, 20(1), 21-37.

McElroy, G. (2006) 'Committee representation in the European Parliament', European Union Politics, 7(1), 5-29.

Ott, D. (2000) Small Is Democratic: An Examination of State Size and Democratic Development, Garland Publishing.

Panke, D. (2010) Small States in the European Union. Coping with Structural Disadvantages, Ashgate: Farnham, UK. 
Panke, D. (2012) 'Being small in a big union: punching above their weights? How small states prevailed in the vodka and the pesticides cases cases', Cambridge Review of International Affairs, 25(3), 329-344.

Sikk, A. (2009a) 'Force Mineure? The Effects of the EU on Party Politics in a Small Country: The Case of Estonia', Journal of Communist Studies and Transition Politics, 25(4), 468-490.

Sikk, A. (2009b) The 2009 European Elections in Estonia, 41, European Parties Elections and Referendums Network. European Parliament election briefing, Brighton.

Srebrnik, H. (2004) 'Small island nations and democratic values', World Development, 32(2), 329-341.

Steinmetz, R., Wivel, A. (Eds.) (2010) Small States in Europe. Challenges and Opportunities., Ashgate: Farnham, UK.

Taagepera, R. (2007) Predicting Party Sizes: The Logic of Simple Electoral Systems, Oxford University Press.

Taagepera, R. (2008) Making Social Sciences More Scientific: The Need for Predictive Models: The Need for Predictive Models, Oxford University Press.

Taagepera, R., Hosli, M. (2006) 'National representation in international organizations: the seat allocation model implicit in the European Union Council and Parliament', Political Studies, 54(2), 370-398.

Taagepera, R., Recchia, S. (2002) 'The size of second chambers and European assemblies', European Journal of Political Research, 41(2), 165-185.

Taagepera, R., Shugart, M. (1989) Seats and Votes: The Effects and Determinants of Electoral Systems, New Haven: Yale University Press.

Thorhallsson, B. (2006) 'The Size of States in the European Union: Theoretical and Conceptual Perspectives', Journal of European Integration, 28(1), 7-31.

Trapans, J.A. (1998) 'The Baltic states: Defence and geopolitics', European Security, 7(3), 92100.

Tulmets, E. (2014) East Central European Foreign Policy Identity in Perspective: Back to Europe and the EU's Neighbourhood, Palgrave Macmillan.

Weldon, S. (2006) 'Downsize my polity? The impact of size on party membership and member activism', Party Politics, 12(4), 467-481. 